\title{
ANALISIS PENGARUH PENAGIHAN PAJAK DENGAN SURAT PAKSA TERHADAP PENERIMAAN PAJAK DI KANTOR PELAYANAN PAJAK PRATAMA ARGAMAKMUR PROVINSI BENGKULU
}

\author{
Adhitya Yuspitara \\ Karona Cahya Susena \\ Herlin \\ Fakultas Ekonomi Universitas Dehasen Bengkulu \\ Karona_cs@yahoo.co.uk
}

\begin{abstract}
ABSTRAK
Adhitya Yuspitara, Karona Cahya Susena, Herlin; Tujuan dari penelitian ini adalah untuk memberikan gambaran umum tentang tindakan pemungutan pajak dengan surat paksa di kantor pajak Pratama Argamakmur, Mengetahui pengaruh pemungutan pajak dengan surat paksa di kantor dinas pajak pramama argamakmur untuk meningkatkan penerimaan pajak di KPP Prtama Argamakmur khususnya pajak penghasilan badan. Metode pengumpulan data yang digunakan adalah data sekunder berupa dokumentasi. Metode analisis yang digunakan adalah analisis regresi linier sederhana dan uji hipotesis dengan uji t.

Berdasarkan hasil penelitian dan analisis data pengaruh pemungutan pajak dengan surat kuasa terhadap penerimaan pajak di kantor pajak Pratama Argamakmur dapat menarik kesimpulan dari hasil analisis korelasi sederhana, nilai regresi linier sederhana $Y=7,105,100,391+977.683 .917 \mathrm{X}$ value $=0,803$ Koefisien determinasi $=0,645$ dan nilai $t$ hitung lebih besar dari $t$ tabel adalah 5,714> 1,725 hal ini menunjukkan bahwa Ho ditolak dan Ha diterima yang berarti ada pengaruh pemungutan pajak dengan surat Memaksa melawan penerimaan pajak
\end{abstract}

\section{ABSTRACT}

Adhitya Yuspitara, Karona Cahya Susena, Herlin; The purpose of this study is to provide an overview of tax collection actions with a forced letter made in the tax office Pratama Argamakmur, Knowing the effect of tax collection by a forced letter in the tax service office pramama argamakmur in order to increase tax revenue in KPP Prtama Argamakmur in particular corporate income tax. Data collection method used is secondary data in the form of documentation. The method of analysis used is simple linear regression analysis and hypothesis testing with $t$ test.

Based on the results of research and data analysis on the effect of tax collection with a letter of force against tax revenue in the tax office Pratama Argamakmur can draw the conclusion of the results of simple correlation analysis, simple linear regression value $Y=7.105 .100,391+977.683,917 X \quad r$ value $=0,803$ The coefficient of determination $=0.645$ and the value of $t$ arithmetic greater than $t$ table is 5,714>1.725 it indicates that Ho is rejected and Ha received which means that there is influence of tax collection with the letter of force against the tax revenue.

Key Words: Tax collection and Tax Receipts

\section{PENDAHULUAN}

Indonesia adalah negara berkembang yang melaksanakan pembangunan. Salah satu kegiatan pembangunan yang dilakukan adalah pembangunan nasional. Pembangunan nasional adalah kegiatan yang berlangsung secara terus menerus dan berkesinambungan. Pembangunan tersebut bertujuan untuk mencerdaskan kehidupan bangsa dan untuk mensejahterakan rakyat indonesia secara adil makmur dan merata. Agar tujuan tersebut dapat terwujud maka di butuhkan dana. Dana ini salah satunya berasal dari penerimaan pajak. Pajak merupakan pendapatan negara yang cukup potensial untuk dapat mencapai keberhasilan pembangunan. Peneriman dari sektor pajak ternyata salah satu sumber penerimaan terbesar negara. Menurut (Andriani dalam Bohari 2012:23) Pajak adalah iuran masyarakat kepada Negara (yang dipaksakan) yang menurut peraturan-peraturan umum (undang-undang) dengan tidak mendapat prestasi kembali yang langsung dapat ditunjuk dan yang gunanya adalah untuk membiayai pengeluaranpengeluaran umum berhubung tugas Negara untuk menyelenggarakan fungsi pemerintahan. Dari tahun ke tahun terlihat bahwa penerimaan pajak terus meningkat dan memberi andil besar dalam penerimaan negara. Penerimaan dari sektor pajak selalu dikatakan primadona dalam membiayayi pembangunan nasional. 
Pembangunan nasional ini diharapkan tidak hanya dapat mengubah keadaan kehidupan ekonomi yang lebih baik juga mampu menimbulkan dorongan dan tuntutan untuk mengadakan modernisasi di segala bidang kehidupan masyarakat. Untuk mencapai tujuan pembangunan nasional tersebut diperlukan investasi dalam jumlah besar yang pelaksanaannya harus berlandaskan pada kemampuan sendiri. Oleh karena itu perlu diletakkan suatu landasan yang dapat menjamin tersedianya dana dari sumber-sumber di dalam negeri guna melepaskan diri dari ketergantungan pada sumber luar negeri sehingga bantuan luar negeri hanya merupakan pelengkap yang makin lama makin kecil peranannya. Salah satu sumber dana dari dalam negeri adalah pajak. Dilihat dari segi ekonomi, pajak adalah sumber penerimaan negara paling potensial.

Masyarakat yang mandiri dan peduli, diharapkan mempunyai kesadaran yang tinggi dalam melaksanakan kewajiban sebagai warga negara untuk membantu bangsanya dalam mewujudkan tujuan mulia. Direktorat Jenderal Pajak sebagai pengayom perpajakan di Indonesia dengan program-programnya sudah berusaha untuk menekan sekecil mungkin tunggakan pajak. Pelayanan yang lebih baik, pembinaan, penyuluhan, sosialisasi, pengawasan, bahkan sanksi-sanksi perpajakan telah diterapkan guna meminimalisasi tunggakan pajak dan diharapkan wajib pajak lebih patuh. Tetapi pada kenyataannya masih saja ada penyimpangan yang dilakukan wajib pajak untuk menghindari kewajiban perpajakannya. Adanya penyimpangan berupa pelanggaran yang dilakukan wajib pajak tersebut itulah yang menyebabkan tunggakan pajak terus meningkat. Sehubungan dengan hal itu, tindakan penagihan pun dilakukan. Tindakan penagihan pajak didasari oleh adanya Surat Ketetapan Pajak, yaitu seperti: Surat Tagihan Pajak (STP), Surat Ketetapan Pajak Kurang Bayar (SKPKB). Ketetapan Pajak Kurang Bayar Tambahan (SKPKBT), Surat Keputusan Pembetulan, serta Surat Keputusan Keberatan dan Putusan Banding yang menyebabkan jumlah pajak yang harus dibayar ditambah. Oleh karenanya harus dilakukan tindakan penagihan yang mempunyai kekuatan hukum memaksa. Salah satu wujud tindakan penagihan yang terdapat dalam Undang-Undang Nomor 19 Tahun 2000 tentang penagihan pajak dengan surat paksa adalah dengan diterbitkan dan disampaikannya surat paksa, yang bersifat parate eksekusi, yang memiliki kekuatan eksekutorial (executorial title) dan mempunyai kekuatan hukum yang pasti sehingga dapat langsung dilaksanakan tanpa melalui proses pengadilan.

Penagihan pajak merupakan serangkaian tindakan agar penanggung pajak melunasi utang pajak dan biaya penagihan pajak dengan cara menegur atau memperingatkan, melaksanakan penagihan seketika dan sekaligus, memberitahukan surat paksa, mengusulkan pencegahan, melaksanakan penyitaan, melaksanakan penyanderaan, dan menjual barang yang telah disita (Suandy, 2008:173). Tindakan tersebut berupa penagihan pajak pasif melalui himbauan dengan menggunakan surat tagihan atau surat ketetapan pajak. Dan selanjutnya berupa penagihan pajak aktif yang meliputi penerbitan surat teguran, pemberitahuan surat paksa, melaksanakan penyitaan, serta menjual barang yang telah disita berdasarkan ketentuan yang diatur dalam Undang-Undang Nomor 19 tahun 1997 Tentang Penagihan Pajak dengan Surat Paksa sebagaimana telah diubah dengan Undang-Undang Nomor 19 Tahun 2000.

Undang-undang penagihan pajak ini diharapkan dapat memberikan kepastian hukum dan keadilan serta dapat mengurangi tunggakan pajak yang terjadi. Dengan dilaksanakannya tindakan Penagihan Pajak dengan Surat Paksa diharapkan Wajib Pajak menjadi lebih patuh dan tunggakan pajak dapat berkurang sehingga penerimaan negara dari sektor pajak diharapkan mencapai target bahkan surplus agar pembangunan nasional berjalan lancar. Dalam pelaksanaannya, penagihan pajak dengan surat paksa terdapat banyak kendala sehingga penerimaan negara dari sektor pajak tidak bisa secara mudah masuk ke kas negara begitu saja.

\section{LANDASAN TEORI Pajak}

Pengertian pajak dan pandangan para ahli dalam bidang tersebut memberikan berbagai definisi tentang pajak yang berbeda-beda, tetapi pada dasarnya definisi tersebut mempunyai tujuan yang sama. Untuk lebih jelasnya dan untuk memahami pengertian tentang apa yang dimaksud dengan pajak, maka dikemukakan beberapa definisi pajak sebagai berikut:

Undang - undang No.28 Tahun 2007 tentang Perubahan Ketiga atas Undang - Undang No.6 Tahun 1983 tentang Kententuan Umum dan Tata Cara Perpajakan (KUP) bahwa:

"Pajak adalah kontribusi wajib pajak kepada negara yang terutang oleh orang pribadi atau badan yang bersifat memaksa berdasarkan undang - undang dengan tidak mendapatkan imbalan secara langsung dan digunakan digunakan untuk keperluan negara bagi sebesar - besarnya kemakmuran rakyat".

Menurut Mardiasmo (2011: 1) bahwa : 
"Pajak adalah iuran rakyat kepada kas negara berdasarkan undang - undang (yang dapat dipaksakan) dengan tidak mendapat jasa timbal (kontraprestasi) yang langsung dapat ditujukan dan yang digunakan untuk membayar pengeluaran umum".

Bedasarkan pengertian di atas kesimpulan pajak adalah pungutan atau kontribusi wajib kepada negara yang terutang oleh orang pribadi atau badan yang bersifat memaksa berdasarkan Undang-undang, dengan tidak mendapatkan imbalan secara langsung dan digunakan untuk keperluan negara bagi sebesarbesarnya kemakmuran rakyat."

\section{Syarat Pemungutan Pajak}

Agar pemungutan pajak tidak menimbulkan hambatan atau perlawanan, maka menurut Mardiasmo (2011:2) pemungutan pajak harus memunuhi syarat sebagai berikut:

a. Pemungutan pajak harus adil (syarat keadilan) Undang dan pelaksanaan pemungutan harus adil. Adil dalam perundang - undangan diantaranya mengenakan pajak secara umum dan merata, serta disesuaikan dengan kemampuan masing - masing. Sedangkan adil dalam pelaksanaanya yakni dengan memberikan hak bagi wajib pajak untuk mengajukan keberatan, penundaan dalam pembayaran dan mengajukan banding kepada pertimbangan pajak.

b. Pemungutan pajak harus berdasarkan Undang - undang (syarat yuridis) Di Indonesia, pajak diatur dalam UUD 1945 pasal 23 ayat 2. Hal ini memberikan jaminan hukum untuk menyatakan keadilan, baik Negara maupun warganya.

c. Tidak mengganggu perekonomian (syarat ekonomi) Pemungutan tidak boleh mengganggu kelancaran kegiatan produksi maupun perdagangan sehingga tidak menimbulkan kelesuan perekonomian masyarakat.

d. Pemungutan pajak harus efisien (syarat financial) Sesuai dengan budgeteir, biaya pemungutan pajak harus dapat ditekan sehingga lebih rendah dari hasil pemungutannya

e. Sistem pemungutan pajak harus sederhana Sistem pemungutan sederhana akan memudahkan dalam mendorong masyarakat untuk memenuhi kewajiban perpajakannya. Syarat ini telah dipenuhi oleh undang - undang perpajakan yang baru.

\section{Sistem Pemungutan Pajak}

Menurut Mardiasmo (2011:7), Sistem pemungutan pajak dapat dibagi menjadi 3 yaitu :

a. Official Assessment System, Sistem ini merupakan sistem pemungutan pajak yang member wewenang kepada pemerintah untuk menentukan besarnya pajak yang terutang.

b. Self Assessment System, Sistem ini merupakan pemungutan pajak yang memberikan wewenang, kepercayaan, tanggung jawab kepada Wajib Pajak untuk menghitung, memperhitungkan, membayar dan melaporkan sendiri besarnya pajak yang harus dibayar

c. Withholding System, Sistem ini merupakan sistem pemungutan pajak yang memberi wewenang kepada pihak ketiga untuk memotong atau memungut besarnya pajak yang terutang oleh Wajib Pajak.

\section{Teori-Teori Yang Mendukung Pemungutan Pajak}

Atas dasar apakah negara mempunyai hak untuk memungut pajak? Menurut Agus dan Trisnawati (2013:5 ) beberapa teori yang mendukung hak negara untuk memungut pajak dari rakyatnya, antara lain.

1. Teori asuransi

Teori ini menyatakan bahwa negara bertugas untuk melindungi orang dan segala kepentingannya, meliputi keselamatan dan keamanan jiwa, dan juga harta bendanya. Seperti halnya dalam perjanjian asuransi (pertanggungan), untuk melindungi orang dan kepentingan tersebut diperlukan pembayaran premi. Dalam hubungan negara dengan rakyatnya, pajak inilah yang dianggap sebagai premi tersebut yang sewaktu-waktu harus dibayar oleh masing-masing individu.

2. Teori kepentingan

Teori ini awalnya hanya memperhatikan pembagian beban pajak yang harus dipungut dari seluruh penduduk. Pembagian beban ini harus didasarkan atas kepentingan masing-masing orang dalam tugas-tugas pemerintah, termasuk perlindungan atas jiwa orang-orang itu beserta harta bendanya. Oleh karena itu sudah sewajarnya jika biaya-biaya yang dikeluarkan oleh negara dibebankan kepada mereka.

3. Teori gaya pikul

Teori ini mempersoalkan asal mula negara memungut pajak, melainkan hanya melihat pada efeknya, dan memandang efek yang baik itu sebagai dasar keadilannya. Menurut teori ini, fungsi pemungutan 
pajak disamakan dengan pompa, yaitu mengambil gaya beli dari rumah tangga dalam masyarakat untuk rumah tangga negara, dan kemudian menyalurkan kembali ke masyarakat dengan maksud untuk memelihara hidup masyarakat dan untuk membawanya ke arah tertentu. Teori ini mengajarkan bahwa penyelenggaraan kepentingan masyarakat inilah yang dapat dianggap sebagai dasar keadilan pemungutan pajak.

\section{Hambatan Pemungutan Pajak}

Menurut Mardiasmo (2011:8), Hambatan pemungutan pajak dapat dikelompokkan menjadi:

a. Perlawanan pasif

Masyarakat tidak bersedia memenuhi kewajiban perpajakannya sebagaimana mestinya, yang dapat disebabkan antara lain:

1) Perkembangan intelektual dan moral masyarakat

2) Sistem perpajakan yang sulit dipahami masyarakat

3) Sistem kontrol tidak dapat dilakukan atau dilaksanakan dengan baik

b. Perlawanan aktif

Perlawanan aktif meliputi semua usaha dan perbuatan yang secara langsung ditujukan kepada fiskus dengan tujuan untuk menghindari pajak. Bentuknya antara lain :

1) Tax avoidance, yaitu usaha meringankan beban pajak dengan tidak melanggar Undang - undang

2) Tax evasion, yaitu usaha meringankan pajak dengan cara melangar Undang - undang namun tidak dipungkiri bahwa sebagian masyarakat terdapat keengganan memenuhi kewajiban perpajakannya.

\section{Penagihan Pajak}

Hal ini merupakan posisi strategis dalam meningkatkan penerimaan negara dari sektor pajak sehingga tindakan penagihan pajak tersebut dapat menyelamatkan penerimaan pajak yang tertunda. Kegiatan penagihan pajak merupakan ujung tombak dalam menyelamatkan penerimaan Negara yang tertunda, oleh sebab itu seksi penagihan merupakan seksi produksi yang paling dibanggakan oleh Direktorat Jenderal Pajak. Dalam pelaksanaaanya penagihan pajak haruslah dilandaskan pada peraturan perundang - undangan yang berlaku, sehingga mempunyai kekuatan hukum baik bagi wajib pajak maupun aparatur pajaknya. Pengertian penagihan pajak sesuai dengan Pasal 1 ayat 9 Undang-undang Nomor 19 tahun 2000 tentang Perubahan Atas Undang-undang Nomor 19 tahun 1997 tentang Penagihan Pajak yang berbunyi: Penagihan Pajak adalah serangkaian tindakan agar Penanggung Pajak melunasi utang pajak dan biaya penagihan pajak dengan menegur atau memperingatkan, melaksakan penagihan seketika dan sekaligus, memberitahukan Surat Paksa, mengusulkan pencegahan, melaksanakan penyitaan, melaksanakan penyanderaan, menjual barang yang telah disita".

\section{Dasar Penagihan Pajak}

Sesuai Pasal 18 ayat 1 Undang-Undang Nomor 28 Tahun 2007, perubahan ketiga atas UndangUndang Nomor 6 Tahun 1983 tentang Ketentuan Umum dan Tata Cara Perpajakan, bahwa Surat Ketepatan maupun Surat Keputusan yang menjadi dasar penagihan pajak seperti berikut ini :

1. Surat Tagihan Pajak (STP)

Surat Tagihan Pajak adalah surat untuk melakukan tagihan pajak dan/atau sanksi administrasi berupa bunga dan/atau denda

2. Surat Ketetapan Pajak Kurang Bayar (SKPKB)

Surat Ketetapan Pajak Kurang Bayar (SKPKB) adalah surat ketetapan yang menentukan besarnya jumlah pokok pajak, jumlah kredit pajak, jumlah kekurangan pembayaran pokok pajak, besarnya sanksi administrasi, dan jumlah yang masih harus dibayar

3. Surat Ketetapan Pajak Kurang Bayar Tambahan (SKPKBT)

Surat Ketetapan Pajak Kurang Bayar Tambahan (SKPKBT) adalah surat ketetapan pajak yang menentukan tambahan atas jumlah pajak yang telah ditetapkan

4. Surat Keputusan Pembetulan

surat keputusan pembetulan adalah surat keputusan yang membetulkan kesalahan tulis, kesalahan hitung, dan/atau kekeliruan penerapan ketentuan tertentu dalam peraturan perundang-undangan perpajakan yang terdapat dalam surat ketetapan pajak, surat tagihan pajak, surat keputusan keberatan, surat keputusan pengurangan sanksi administrasi, surat keputusan penghapusan sanksi administrasi, surat keputusan pengurangan ketetapan pajak, surat keputusan pembatalan ketetapan pajak, surat keputusan pengembalian pendahuluan kelebihan pajak, atau surat keputusan pemberian imbalan bunga. 
5. Surat Keputusan Keberatan Surat Keputusan Keberatan adalah surat keputusan atas keberatan terhadap surat ketetapan pajak atau terhadap pemotongan atau pemungutan oleh pihak ketiga yang diajukan oleh Wajib Pajak.

6. Putusan Banding

Putusan Banding adalah putusan badan peradilan pajak atas banding terhadap Surat Keputusan Keberatan yang diajukan oleh Wajib Pajak.

\section{Tindakan Penagihan Pajak}

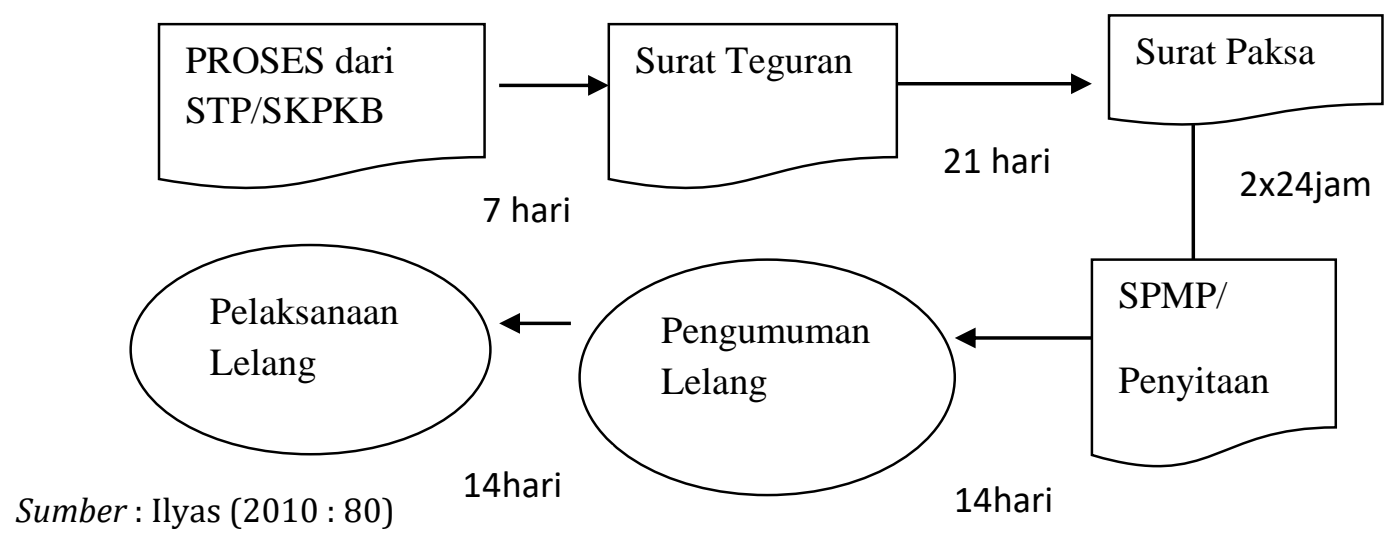

Gambar 1. Tindakan alur penagihan pajak

Kegiatan penagihan pajak sejak tanggal jatuh tempo pembayaran sampai dengan pengajuan permintaan penetapan tanggal dan pelelangan meliputi jangka waktu 58 hari. Hal tersebut dapat dijelaskan sebagai berikut :

1. Pejabat menerbitkan surat teguran, surat peringatan, atau surat lain yang sejenis apabila penanggung pajak tidak melunasi utang pajaknya dalam jangka waktu 7 hari setelah jatuh tempo.

2. Selanjutnya surat paksa diterbitkan apabila dalam jangka waktu 21 hari setelah surat teguran, surat peringatan, atau surat lain yang sejenis diterbitkan namun penanggung pajak masih juga belum melunasi utang pajaknya. Kewajiban pajak sebagaimana tertuang dalam surat paksa harus dilunasi dalam jangka waktu $2 \times 24$ jam.

3. Apabila utang pajak belum dilunasi dalam jangka waktu sebagaimana tertuang dalam surat paksa yaitu 2x24 jam, maka pejabat dapat menerbitkan Surat Perintah Melaksanakan Penyitaan (SPMP).

4. Empat belas hari setelah dilakukan penagihan pajak dengan Surat Perintah Melaksanakan Penyitaan (SPMP), ternyata penanggung pajak belum melunasi utang pajaknya, pejabat menerbitkan surat perintah tentang pengumuman lelang.

5. Empat belas hari setelah pengumuman lelang ternyata penanggung pajak masih belum juga melunasi utang pajaknya, pejabat melakukan penjualan barang sitaan penanggung pajak melalui Kantor Lelang Negara

\section{Penagihan Pajak Dengan Surat Paksa}

Surat paksa adalah surat perintah membayar utang pajak dan biaya penagihan pajak. Surat paksa berkepala kata-kata Demi Keadilan Berdasarkan Ketuhanan Yang Maha Esa. Agar tercapai efektivitas dan efisiensi penagihan pajak yang didasari dengan surat paksa, maka surat paksa mempunyai kekuatan hukum eksekutorial dan kedudukan hukum yang sama dengan grosse akte yaitu putusan pengadilan perdata yang telah mempunyai kekuatan hukum tetap. Dengan demikian, surat paksa langsung dapat dilaksanakan tanpa bantuan putusan pengadilan lagi dan tidak dapat diajukan banding. Dalam Pasal 7 ayat 2 (UU Penagihan Pajak), disebutkan bahwa surat paksa sekurang-kurangnya harus memuat :

1) Nama Wajib Pajak atau nama Wajib Pajak dan penanggung pajak.

2) Dasar penagihan.

3) Besarnya utang pajak.

4) Perintah untuk membayar.

\section{Undang-Undang Penagihan Pajak dengan Surat Paksa (PPSP)}

Menurut Fidel (2010: 47) UU PPSP (Penagihan Pajak dengan Surat Paksa) yaitu :

1. Falsafah UU PPSP No.19/2000 
a) Menampung perkembangan sistem hukum nasional perlunya dipertegaskan perolehan hak karena waris dan hibah wasiat yang merupakan objek pajak

b) Mendorong peningkatan kesadaran dan kepatuhan masyarakat dalam memenuhi kewajiban perpajakannya

c) Adanya kepastian hukum dan menegakkan keadilan

2. Tujuan perubahan UU PPSP No.19/2000

a) Banyaknya tunggakan pajak dari waktu ke waktu menunjukkan jumlah yang semakin besar, untuk itu perlu dilaksanakan tindakan penagihan pajak yang mempunyai kekuatan hukum yang memaksa

b) Kepatuhan Wajib Pajak dalam membayar pajak merupakan posisi strategis dalam peningkatan penerimaan pajak

c) Penagihan pajak yang dilaksanakan secara konsisten dan berkesinambungan merupakan wujud lawan enfercoment untuk meningkatkan kepatuhan yang menimbulkan aspek psikologis bagi Wajib Pajak

d) Memberikan perlindungan hukum, baik kepada penanggung pajak maupun kepada pihak ketiga berupa hak untuk mengajukan gugatan.

3. Hal - hal yang menjadi perhatian pada UU PPSP No.19/2000

a) Mempertegaskan proses pelaksanaan penagihan pajak dengan menambahkan ketentuan Penerbitan Surat Teguran, Surat Peringatan dan Surat Lain yang sejenisnya sebelum Surat Paksa dilaksanakan

b) Mempertegas jangka waktu pelaksanaan penagihan aktif

c) Mempertegas pengertian penanggung pajak yang meliputi komisaris, pemegang saham, pemilik modal

d) Menaikkan nilai peralatan usaha yang dikecualikan dari penyitaan dalam rangka menjaga kelangsungan usaha penanggung pajak

e) Menambah jenis barang yang penjualannya dikecualikan dari lelang

f) Mempertegas bahwa pengajuan keberatan atau permohonan banding oleh wajib pajak tidak menunda pembayaran dan pelaksanaan penagihan pajak

g) Memberi kemudahan pelaksanaan lelang dengan cara memberi batasan nilai barang yang diumumkan tidak melalui media massa dalam rangka efisiensi

h) Memperjelas hak penanggung pajak untuk memperoleh ganti rugi dan permulihan nama baik dalam hal gugatannya dikabulkan

i) Mempertegas pemberian sanksi pidana kepada pihak yang sengaja mencegah, menghalang halangi atau menggagalkan pelaksanaan penagihan pajak

\section{Penerbitan Surat Paksa}

Menurut pasal 8 ayat (1) UU PPSP (penagihan pajak dengan surat paksa) diterbitkan apabila:

1) Penanggung pajak tidak melunasi utang pajak sampai dengan tanggal jatuh tempo pembayaran dan kepadanya telah diterbitkan surat teguran atau surat peringatan atau surat lain yang sejenis

2) Terhadap penanggung pajak telah dilaksanakan penagihan pajak seketika dan sekaligus

3) Penanggung pajak tidak memenuhi ketentuan sebagaimana tercantum dalam keputusan persetujuan angsuran atau penundaan pembayaran pajak

\section{Pelaksanaan Surat Paksa}

Menurut KUP (ketentuan umum perpajakan) Surat Paksa merupakan kegiatan pelaksanaan penagihan pajak yang dilakukan setelah penerbitan Surat Teguran / Surat Peringatan atau sejenisnya. Menurut pasal 1 angka 12 UU Penagihan Pajak, Surat Paksa adalah surat perintah membayar utang pajak dan biaya penagihan pajak pelaksanaanya dilakukan sebagai berikut:

a. Surat paksa memuat jumlah utang pajak dan biaya penagihan pajak sebagaimana mestinya.

b. Surat paksa dikirim melalui pos wesel walaupun tercatat atau oleh juru sita yang di tunjuk. Surat paksa tidak perlu ditandatangani oleh pejabat pajak yang menerbitkan

\section{KERANGKA ANALISIS}

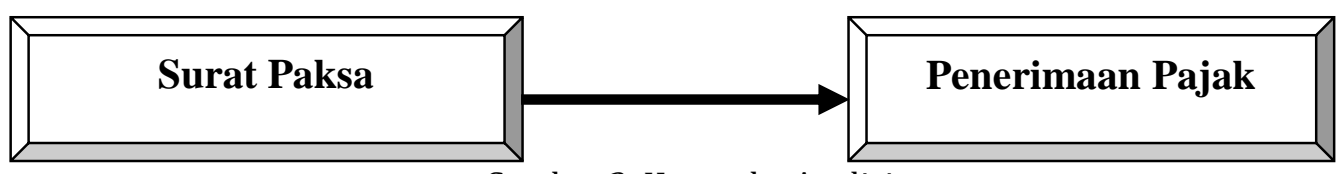

Gambar 2. Kerangka Analisis 


\section{Hipotesis}

Ho : Tidak ada pengaruh penagihan pajak dengan surat paksa terhadap penerimaan pajak di kantor pelayanan pajak pratama Argamakmur Provinsi Bengkulu

Ha : Ada pengaruh penagihan pajak dengan surat paksa terhadap penerimaan pajak di kantor pelayanan pajak pratama Argamakmur Provinsi Bengkulu

\section{METODOLOGI}

Pada penelitian ini penulis menggunakan metode pendekatan deskriptif kuantitatif, yaitu suatu bentuk penelitian yang dilakukan berdasarkan data data yang sesuai dengan sebenarnya yang dikumpulkan selama penelitian disertai analisis dan interprestasikan berdasarkan teori-teori dan literatur-literatur yang berhubungan dengan penelitian yang penulis ambil dalam hal ini mengenai penagihan pajak dengan surat paksa terhadap penerimaan pajak kemudian data itu disusun,diolah dan di analisis dalam pengujian hipotesis statistik.

Untuk mendapatkan data yang lebih lengkap dan akurat, maka penulis menggunakan metode jenis data sekunder yaitu berupa dokumentasi yang diperoleh langsung dari kantor pelayanan pajak pratama Argamakmur berupa laporan penagihan, laporan penerimaan pajak dan laporan surat paksa selaman 20 bulan dari januari 2015 sampai agustus 2016 yaitu sebanyak 310 wajib pajak penghasilan badan yang mendapatkan surat paksa.

Analisis regresi linier sederhana digunakan untuk menentukan dasar ramalan dari suatu distribusi data yang terdiri dari variabel akibat/dependent (penerimaan pajak) dan satu variabel faktor penyebab/independent (surat paksa) yang memiliki bentuk hubungan linier. Adapun regresi sederhana dapat dirumuskan sebagai berikut:

Keterangan:

$$
\mathrm{Y}=\mathrm{a}+\mathrm{bX}
$$

$\mathrm{Y}=$ variabel akibat/dependent (penerimaan pajak)

$\mathrm{X}=$ variabel faktor penyebab/independent (surat paksa)

$\mathrm{a}=$ bilangan konstan

$\mathrm{b}=$ koefisien arah regresi linear.

\section{HASIL PENELITIAN DAN PEMBAHASAN Regresi linier sederhana}

Analisis linier sederhana adalah hubungan secara linier antara variabel independent $\mathrm{X}$ dan variabel dependet $Y$ analisis ini digunakan untuk mengetahui arah hubungan antara variabel $X$ dan variabel $\mathrm{Y}$ dan untuk mengetahui nilai positif atau negatif.

Tabel 1. Coefficients ${ }^{\mathrm{a}}$

\begin{tabular}{|c|c|c|c|c|c|}
\hline \multirow[b]{2}{*}{ Model } & \multicolumn{2}{|c|}{ Unstandardized Coefficients } & \multirow{2}{*}{\begin{tabular}{|c|}
$\begin{array}{c}\text { Standardized } \\
\text { Coefficients }\end{array}$ \\
Beta
\end{tabular}} & \multirow[b]{2}{*}{$\mathrm{t}$} & \multirow[b]{2}{*}{ Sig. } \\
\hline & B & Std. Error & & & \\
\hline 1 (Constant) & 7105100.391 & 3009111.029 & & 2.361 & .030 \\
\hline SURATPAKSA & 977683.917 & 171099.308 & .803 & 5.714 & .000 \\
\hline
\end{tabular}

a. Dependent Variable: PENERIMAANPAJAK

Sumber :Data olahan SPSS 16

Hasil penghitungan koefisien regresi sederhana diatas memperlihatkan nilai koefisien konstanta adalah sebesar 7.105.100,391 koefisien variabel bebas (X) adalah sebesar 977.683,917 Sehingga diperoleh persamaan regresi $Y=7.105 .100,391+977.683,917 X$.

Berdasarkan persamaan diatas diketahui nilai konstantanya sebesar 7.105.100,391 secara matematis, nilai konstanta ini menyatakan bahwa pada saat penerimaan pajak 0 , maka surat paksa memiliki nilai $977.683,917$, Selanjutnya nilai positif $(977.683,917)$ yang terdapat pada koefisien regresi variabel bebas (Surat Paksa) menggambarkan bahwa arah hubungan antara variabel bebas (Surat Paksa) dengan variabel terikat (Penerimaan Pajak) adalah searah, dimana setiap kenaikan satu satuan variabel surat paksa akan akan menyebabkan kenaikan penerimaan pajak 977.683,917. 


\section{Koofisien Determinasi $\left(\mathbf{r}^{2}\right)$}

Analisis koofisien determinasi $\left(\mathrm{r}^{2}\right)$ digunakan untuk mengetahui kekuatan pengaruh panagihan Pajak dengan surat paksa (variabel $\mathrm{X}$ ) terhadap penerimaan pajak (Variabel $\mathrm{Y}$ ), Berikut disajikan dalam tabel di bawah ini :

Tabel 2 . Model Summary

\begin{tabular}{|c|r|r|r|c|}
\hline Model & \multicolumn{1}{|c|}{$\mathrm{R}$} & \multicolumn{1}{|c|}{ R Square } & Adjusted R Square & $\begin{array}{c}\text { Std. Error of the } \\
\text { Estimate }\end{array}$ \\
\hline 1 & $.803^{\mathrm{a}}$ & .645 & .625 & 6358359.684 \\
\hline
\end{tabular}

a. Predictors: (Constant), SURATPAKSA

Sumber :Data olahan SPSS 16

Tabel 2. menampilkan nilai R yang merupakan simbol dari nilai koofisient korelasi pada tabel Nilai $\mathrm{R}$ adalah 0,803 . Nilai ini dapat diinterpretasikan bahwa hubungan kedua variabel penelitian berada pada kategori kuat karena nilai R mendekati (1). Melalui tabel diatas juga diperoleh nilai R Square atau koefisien Determinasi (KD) yang menunjukkan seberapa bagus model regresi yang dibentuk oleh interaksi variabel bebas dan variabel terikat. Nilai KD yang diperoleh adalah 64,5\%. Sehingga dapat ditafsirkan bahwa variabel bebas X memiliki pengaruh kontribusi sebesar $64,5 \%$ terhadap variabel $\mathrm{Y}$ sedangkan $35.5 \%$ lainya di pengaruhi oleh faktor lain di luar variabel X.

\section{Uji Hipotesis}

Uji hipotesis merupakan pengujian yang akan lakukan dalam penelitian yang berkaitan dengan ada atau tidaknya pengaruh yang signifikan antara penagihan pajak dengan surat paksa dengan penerimaan pajak di kantor KPP Argamakmur Provinsi bengkulu dalam hal ini di uji menggunakan Uji T dan dapat dilihat pada tabel 1. diatas.

a) Perumusan Hipotesis

Ho : Tidak ada pengaruh penagihan pajak dengan surat paksa terhadap penerimaan pajak di kantor pelayanan pajak pratama Argamakmur Provinsi Bengkulu

Ha :Ada pengaruh penagihan pajak dengan surat paksa terhadap penerimaan pajak di kantor pelayanan pajak pratama Argamakmur Provinsi Bengkulu

b) Penetapan kriteria

Besarnya nilai t tabel untuk taraf signifikan $5 \% \mathrm{db}=18(\mathrm{db}=\mathrm{N}-2$ untuk $\mathrm{N}=20)$ yaitu 1,725

c) Hasil thitung

Hasil thitung diperoleh dengan menggunakan SPSS 16.0 yaitu sebesar 5.714

d) Pengambilan keputusan

Jika t hitung lebih besar dari t tabel maka Ha diterima dan Ho ditolak. Dari hasil perhitungan t hitung sebesar 5.714 di atas dibandingkan dengan $t$ tabel $(\mathrm{db}=18)$ yaitu 1,725 taraf signifikan $5 \%$, jadi $t$ hitung $>\mathrm{t}$ tabel maka Ha diterima dan Ho di tolak. Dengan kata lain menolak hipotesis nol (Ho) dan menerima hipotesis alternatif $(\mathrm{Ha})$ untuk pengujian kedua variabel.

\section{Pembahasan}

Masih banyaknya tunggakan pajak di KPP Argamakmur provinsi Bengkulu khusus nya pajak penghasilan badan mengakibatkan berkurangnya penerimaan pajak, Yang dimaksud penghasilan badan di sini adalah sekumpulan orang /atau modal yang merupakan kesatuan, baik yang melakukan usaha maupun yang tidak melakukan usaha yang meliputi perseroan terbatas (PT), perseroan komanditer (CV), perseroan lainnya, badan usaha milik negara atau badan usaha milik daerah dengan nama dan dalam bentuk apa pun, firma, kongsi, koperasi, dana pensiun, persekutuan, perkumpulan, yayasan, organisasi massa, organisasi sosial politik, atau organisasi lainnya, lembaga dan bentuk badan lainnya termasuk kontrak investasi kolektif dan bentuk usaha tetap (UU Nomor 28 tahun 2007).

Dengan dilaksanakannya tindakan Penagihan Pajak dengan Surat Paksa diharapkan Wajib Pajak menjadi lebih patuh dan tunggakan pajak dapat berkurang, dengan berkurangnya penerimaan pajak maka fungsi pajak tidak akan terlaksana dengan baik seperti Fungsi Penerimaan (Budgetair), Fungsi Mengatur (Regulerend), Fungsi Pemerataan dan Fungsi Stabilisasi. 
Dalam penelitian ini surat paksa berpengaruh signifikan terhadap penerimaan pajak, hal ini berarti apabila surat paksa diterbitkan maka penerimaan pajak yang ditrima semakin banyak. Bedasarkan hasil regresi sederhana yaitu Y=7.105.100,391+977.683,917X, maka dari itu dapat di katakan bahwa persamaan regresi ini (surat paksa) bernilai positif ( + ) terhadap (penerimaan pajak) dan menunjukkan hubungan yang searah antara variabel X dan Variabel Y dimana setiap kenaikan satu satuan surat paksa maka menyebabkan kenaikan penerimaan pajak sebesar $977.683,917 \mathrm{X}$ hal ini sesuai dengan teori yang di tulis oleh Siregar (2011:392).

Berdasarkan hasil analisis yang telah diuraikan di atas diperoleh hasil bahwa variabel $(\mathrm{X})$ surat paksa berpengaruh sangat kuat terhadap variabel $(\mathrm{Y})$ penerimaan pajak Di KPP Pratama Argamakmur Provinsi Bengkulu. Hal tersebut ditunjukkan dari hasil analisis nilai $\mathrm{R}$ sebesar 0,803 Nilai ini dapat diinterpretasikan bahwa hubungan kedua variabel penelitian berada pada kategori sangat kuat karena nilai R mendekati (1) maka dapat ditarik bahwa hipotesis nol (Ho) ditolak dan (Ha) diterima. Dengan koefisien determinasi sebesar $64.5 \%$ maka berpengaruh positif, artinya jika semakin banyak surat paksa yang dilunasi maka semakin penerimaan pajak KPP Pratama Argamakmur. Sedangkan 35,5\% merupakan faktor yang mempengaruhi variabel $\mathrm{Y}$ dari faktor lain yang tidak diteliti oleh peneliti. Yang tidak diteliti diantaranya sistem pemungutan pajak (assigment system),surat teguran,surat perintah melakukan pelelangan dan lain-lain.

Dari hasil analisi uji t diketetahui bahwa ada pengaruh yang signifikan variabel $(\mathrm{X})$ surat paksa dan variabel (Y) penerimaan pajak. Hal ini dibuktikan Jika t hitung lebih besar dari t tabel maka H0 ditolak dan Ha ditrima artinya penagihan pajak dengan surat paksa berpengaruh signifikan terhadap penerimaan pajak dengan hasil perhitungan uji t sebesar 5.714, sedangkan pada t tabel adalah 1,734 pada taraf signifikansi 5\% yang berarti bahwa Ha diterima jadi kesimpulanya adalah ada Pengaruh penagihan pajak dengan surat paksa terhadap penerimaan pajak di kantor KPP Argamakmur Provinsi Bengkulu. Hasil penelitian ini juga mendukung hasil penelitian sebelumnya yang dilakukan oleh Fajri (2015) dan Hariani (2014) yang menunjukkan hasil yang signifikan .

Dari hasil di atas dapat dilihat bahwa sebelum melakukan penagihan pajak dengan surat paksa tunggakan pajak relatif besar Namun, setelah melakukan penagihan pajak dengan surat paksa terlihat penurunan tunggakan pajak yang menyebabkan penerimaan pajak meningkat, Hal ini menunjukkan bahawa surat paksa berpengaruh terhadap peningkatan penerimaan pajak Hasil uji ini juga memberikan gambaran bahwa wajib pajak badan cenderung akan melunasi utang pajaknya setelah diterbitkan surat paksa

\section{KESIMPULAN}

1. Perolehan persamaan regresi linier $Y=7 \cdot 105 \cdot 100,391+977.683,917 X$. Bedasarkan persamaan tersebut mempunyai arti bahwa, bila surat paksa naik satu satuan maka penerimaan pajak akan naik satu kali 977.683,917X satuan. Tetapi sebaliknya, bila surat paksa di anggap tidak ada (X=0), Maka harga penerimaan pajak akan konstan atau tetap yaitu 7.105.100,391 satuan.

2. Hasil $r$ hitung atau kooffisient determinasi diketahui sebesar 0,803 Nilai tersebut lebih mendekati (1) maka ini berarti pengaruh variabel independen terhadap variabel dependen kuat. Sebaliknya Jika KD mendekati (0), ini berarti pengaruh variabel independen terhadap variabel dependen lemah

3. Hasil perhitungan $\mathrm{t}$ hitung sebesar $5.714 \mathrm{di}$ atas dibandingkan dengan $\mathrm{t}$ tabel $(\mathrm{db}=18)$ yaitu 1,734 taraf signifikan 5\%, jadi t hitung > t tabel maka Ha diterima dan Ho di tolak. Sehingga dapat disimpulkan bahwa variabel $\mathrm{X}$ terdapat pengaruh yang signifikan terhadap variabel $\mathrm{Y}$. Dari hasil pengujian hipotesis tersebut terbukti bahwa "Ada pengaruh penagihan pajak dengan surat paksa terhadap penerimaan pajak di kantor pelayanan pajak pratama Argamakmur Provinsi Bengkulu".

\section{Saran}

Sebaiknya Kantor Pelayanan Pajak Pratama Argamakmur memaksimalkan penagihan pajak agar tidak terjadi lagi tunggakan pajak ,mengurangi surat paksa yang diterbitkan dan mempermudah akses wajib pajak untuk melunasi kewajiban perpajakannya

\section{DAFTAR PUSTAKA}

Budiono, D dan Tarumawijaya, J. 2014. Proses Penagihan Pajak Dengan Surat Paksa Berdasarkan Undangundang Penagihan Pajak Dengan Surat Paksa. Tax \& Accounting Review, Vol.4, No. 1. Uiversitas Kisten Petra. 
Chrissanti,Y 2005. Penagihan Pajak Dengan Surat Paksa Dalam Rangka Meningkatkan Penerimaan Pajak Dan Kepatuhan Wajib Pajak (Pada Kantor Pajak Surabaya) Skripsi Fakultas Ekonomi Universitas Kristen Petra Surabaya.

Fidel. 2010. Cara Mudah dan Praktis Memahami Masalah-Masalah Perpajakan. Jakarta : Murai Kencana

Fajri F. 2015. Pengaruh Wajib Pajak Terhadap Penerimaan Pajak Pada Kantor Pelayanan Pajak Pratama Bengkulu.

Hariani Y. 2014. Pengaruh Tunggakan Pajak Terhadap Realisasi Penagihan Pajak Pada Kantor Pelayanan Pajak Pratama Argamakmur.

Hasan, M. Iqbal, Pokok-pokok Materi Metodologi Penelitian dan Aplikasinya, Ghalia Indonesia, Bogor, 2002.

Ilyas, 2007. Perpajakan Indonesia. Jakarta : Salemba Empat

Mulyadi. 2011. Akuntansi Biaya. Yogyakarya. STIE YPKPN.

Mardiasmo. 2011. Perpajakan Edisi Revisi 2009. Yogyakarta : PT. Andi

Mardiasmo. 2011. Perpajakan edisi Revisi. Yogyakarta : Andi Offset

Mardiasmo. 2011. Perpajakan Edisi Revisi 2011. Yogyakarta : Andi Offset

Prakoso, 2006. Pajak dan Retribusi Daerah. Yogyakarta: UII Press.

Pabuaran. 2005 Analisis Pengaruh Jumlah Wajib Pajak, Pemeriksaaan Pajak Dan Penagihan Pajak Dengan Surat Paksa Terhadap Penerimaan Pajak. Skripsi Fakultas Ekonomi Universitas Hassanudin Makasar.

Undang-undang PPSP. Tentang Pemberitahuan surat paksakepada penanggung pajak.

Undang-undang. No 19/2000. Tentang Penagihan Pajak dengan Surat Paksa Waluyo dan wiraman B.llyas. 2005. Perpajakan Indonesia. Jakarta : Salemba Empat

Undang-Undang Penagihan Pajak, Surat Teguran, Surat Paksa

Undang-Undang PPSP yaitu pemberitahuan Surat Paksa dilakukan oeh juru sita

Resmi, Siti. 2007. Perpajakan Teori dan Kasus Edisi Tiga. Jakarta: Salemba Empat

Santoso 2009. Ketentuan Umum dan tata cara Perpajakan . Bandung : PT. Refika Aditama

Sugiyono. 2010. Sistematika Untuk Penelitian. Bandung : Alfabeta

Sugiyono. 2011 Sistematika Untuk Penelitian. Bandung : Alfabeta

Tmbooks. 2015. Cermat Menguasai Seluk-Beluk Perpajakan Indonesia. Yogyakarta : Cv. Andi Offiset

Undang-undang no. 28. 2007. Tentang Ketentuan Umum dan Tata Cara Perpajakan (KUP)

Undang-Undang Nomor 19 Tahun 2000 tentang Penagihan Pajak dengan Surat Paksa

Undang - undang No.28 Tahun 2007 tentang Perubahan Ketiga atas UndangUndang No.6 Tahun 1983 tentang Kententuan Umum dan Tata Cara Perpajakan (KUP) bahwa

Wijiyanto 2010. Pengaruh Penagihan Pajak Dengan Surat Paksa Terhadap Kepatuhan Wajib Pajak Di Kantor Pelayanan Pajak Pratama Jakarta Mampang Prapatan. Skripsi Fakultas Ekonomi Universitas Negri Jakarta

Waluyo. 2008. Perpajakan Indonesia.. Jakarta : Salemba Empat 